\title{
Note
}

\section{DNA-DNA homology between plasmids from Streptococcus thermophilus}

\author{
Florence GIRARD, Martine LAUTIER, G. NOVEL * \\ IRBA, Institut de Recherche de Biochimie et de Biologie appliquées, \\ Equipe de Génétique microbienne, Université de Caen, 14032 Caen Cedex, France
}

\section{Summary}

Fifty strains of Streptococcus thermophilus isolated from raw milk, industrial starters or issued from collections were studied for their plasmid complement. Most of them did not contain plasmid DNA. Six strains only harboured one plasmid and three strains two plasmids. All these plasmids were small sized: 2.9 to 7.6 kilobases. Restriction analysis and DNA-DNA hybridization were used to demonstrate similarity between plasmids of these strains and to distinguish several homology groups among them.

Key words : Streptococcus thermophilus - Plasmids - DNA-DNA hybridization - Restriction analysis.

\section{Résumé}

Homologie de l'ADN des plasmides de Streptococcus thermophilus

Nous avons étudié le contenu plasmidique de cinquante souches de Streptococcus thermophilus isolées de laits crus, de ferments industriels ou issues de collection. La plupart d'entre elles ne contiennent pas de plasmides. Six souches possèdent un seul plasmide et trois souches possèdent deux plasmides. Tous ces plasmides sont de petite taille : de 2,9 à 7,6 kilobases. L'analyse de restriction et l'hybridation ADN-ADN ont permis de montrer des similitudes entre les plasmides de ces souches et de distinguer plusieurs groupes d'homologie parmi eux.

Mots clés : Streptococcus thermophilus - Plasmides - Hybridation ADN-ADN - Analyse de restriction.

\footnotetext{
* To whom correspondence should be addressed.
} 


\section{Introduction}

Streptococcus thermophilus is used in making dairy products when a high fermentation temperature is necessary (Accolas et al., 1980). This bacterium has only been isolated from heat treated milk (OTTOGAlLi et al., 1978) and milk is considered as its main habitat. In spite of its industrial importance, little is known about this species : few reports have appeared concerning the presence of extrachromosomal elements in this species. Pechmann et al. (1982) claimed the existence of plasmid DNA only in 1 out of 8 strains. SOMKUTI and SteinBerg (1981) described up to 5 plasmids in 26 out of 36 thermophilic strains but they did not differentiate between Streptococcus thermophilus and Lactobacillus bulgaricus. In the report of Davies and GASSON (1983), Davies and UNDERWOOD (unpublished data) mentioned that 18 of 53 strains carried between 2 and 5 plasmids.

Recently, Herman and Mc Kay (1985) analysed 23 strains from commercial starters and collections and found only 5 strains possessing a single plasmid which ranged in size from 2.2 to $3.5 \mathrm{~kb}$. Somkuti and Steinberg (1986) analysed 35 strains and 13 out of them were found to contain plasmid DNA ranging in size from 2.2 to $14.75 \mathrm{~kb}$.

In our study the plasmid complement of 21 strains of $S$. thermophilus that have been isolated from raw milk was examined and compared with 20 strains used as industrial starters and with 9 collection strains. An attempt has been made to establish the extent of homology existing among these extrachromosomal DNA molecules using restriction analysis and DNA-DNA hybridization.

\section{Materials and methods}

\section{A. Strains and cultivation}

Strains were isolated from different samples of raw milk, industrial starters and from the Centre National de Recherche Zootechnique Collection (CNRZINRA, Jouy-en-Josas, France) and were characterized by physiological, biochemical and serological tests. Bacteria were grown in M17 medium (TerzAGHI and SANDine, 1975).

\section{B. Preparation and restriction analysis of plasmid DNA}

Plasmid DNA was isolated according to Anderson and McKAy (1983) and eventually purified in cesium chloride - ethidium bromide density gradient ultracentrifugation $\left(240000 \times g, 22 \mathrm{~h}, 20^{\circ} \mathrm{C}\right)$. Covalently closed circular (CCC) configuration was determined according to HinTERMAnN et al. (1981). Restriction endonucleases were purchased from Bethesda Research Laboratory and used as recommended by the manufacturer. . 


\section{Electrophoresis of plasmid DNA}

Plasmid profiles and plasmid digests were performed on an horizontal slab gel electrophoresis apparatus with 0.6 to $1 \%$ agarose (Sigma, type II) gels in $40 \mathrm{mM}$ Tris-acetate, pH 7.9 and $2 \mathrm{mM}$ di-sodium EDTA running buffer.

Plasmid DNA of ML3 S. lactis (Davies et al., 1981) and Hind III fragments of lambda phage DNA (SANGER et al., 1982) were used as size markers. The average size of plasmids was obtained with at least five measurements. DNA was transferred from gels to nitrocellulose filters (BA85 from Schleicher \& Schuell, GmbH) by the Southern blot technique (Southern et al., 1975).

\section{Preparation of ${ }^{32}$ P-labelled DNA}

Whole plasmid DNA was extracted, purified and nick translated by incubation at $14{ }^{\circ} \mathrm{C}$ for $90 \mathrm{~min}$ with 10 microcuries of ${ }^{32} \mathrm{P}$-labelled dCTP in the presence of DNase and DNA polymerase (Amersham). The reaction was stopped by the addition of $10 \mathrm{mM}$ di-sodium EDTA and unbound labelled nucleotides separated using Sephadex G50 (Pharmacia); before use labelled DNA was boiled for $5 \mathrm{~min}$ and rapidly cooled on ice.

\section{E. DNA-DNA hybridization on filters}

Prehybridization was performed on nitrocellulose filters in Denhardt's solution (MANiATIS et al., 1982) for $2 \mathrm{~h}$ at $60{ }^{\circ} \mathrm{C}$ in the presence of calf thymus DNA (Sigma). Hybridization was carried out for $18 \mathrm{~h}$ at $60{ }^{\circ} \mathrm{C}$; filters were washed 5 times in a solution containing $450 \mathrm{mM} \mathrm{NaCl}, 45 \mathrm{mM}$ tri-sodium citrate, $0.1 \%(\mathrm{w} / \mathrm{v})$ sodium dodecyl sulphate (SDS) and $1 \mathrm{mM}$ di-sodium EDTA, then exposed on X-ray film (Kodak X OMAT AR) for 2 to 3 days.

\section{Results}

A. Number of plasmids in strains of $\mathrm{S}$. thermophilus

50 strains were checked for their agreement with the species $S$. thermophilus and examined for their plasmid complement. No plasmid DNA was detected in 41 strains which included the following strains: CNRZ 160, CNRZ 308, CNRZ 310, CNRZ 368, CNRZ 411, CNRZ 456, CNRZ 560 (NCDO 1611), $\mathrm{HO}_{\mathrm{S}}$ from $\mathrm{D}^{\mathrm{r}} \mathrm{J}$. Stadhouders (NIZO, Department of Microbiology, Ede, Netherlands). Single plasmids were found in 6 strains and 3 contained 2 plasmids. All were checked for CCC configuration. Plasmids were present in 1 out 9 CNRZ collection strains, 2 out of 20 industrial strains, and 6 ont of 21 isolated strains (table 1). 
TABLE 1

Restriction digests from plasmids of $\mathrm{S}$. thermophilus Analyse de restriction des plasmides de $\mathrm{S}$. thermophilus

\begin{tabular}{|c|c|c|c|c|}
\hline Strain & Plasmids .. & $\begin{array}{c}\text { Restriction } \\
\text { Endonucleases }\end{array}$ & $\begin{array}{c}\text { Size }(\mathrm{kb}) \\
\text { of fragment }\end{array}$ & $\begin{array}{c}\text { Total size }(\mathrm{kb}) \\
\text { of plasmid }\end{array}$ \\
\hline $4^{c}$ & $\begin{array}{l}\text { pUCT4a } \\
\text { pUCT4b }\end{array}$ & $\begin{array}{l}\text { Bst EII } \\
\text { Eco RI } \\
M b o \mathrm{I}\end{array}$ & $\begin{array}{l}2.8 \\
2.8 \\
2.4,2.1\end{array}$ & $\begin{array}{l}2.8 \\
2.8 \\
4.5\end{array}$ \\
\hline $43^{b}$ & pUCT43 & $\begin{array}{l}\text { Bgl II } \\
\text { Mbo I } \\
\text { Taq I }\end{array}$ & $\begin{array}{l}5.5,2.0 \\
5.5,1.0,0.9 \\
2.5,1.7,1.0 \\
0.9,0.8,0.7\end{array}$ & $\begin{array}{l}7.5 \\
7.4 \\
7,6\end{array}$ \\
\hline $44^{b}$ & pUCT44 & $\begin{array}{l}\text { Bgl II } \\
\text { Mbo I } \\
\text { Taq I }\end{array}$ & $\begin{array}{l}5.9,2.0 \\
5.4,1.2,1.1 \\
2.3,1.4,1.1 \\
1.0,0.9,0.8\end{array}$ & $\begin{array}{l}7.9 \\
7.7 \\
7.5\end{array}$ \\
\hline $53^{c}$ & $\begin{array}{l}\text { pUCT53a } \\
\text { pUCT53b }\end{array}$ & $\begin{array}{l}\text { Bst } \text { EII } \\
\text { Eco } \text { RI } \\
\text { Eco } \text { RI }\end{array}$ & $\begin{array}{l}3.0 \\
3.0 \\
1.8,1.7\end{array}$ & $\begin{array}{l}3.0 \\
3.0 \\
3.5\end{array}$ \\
\hline $127^{c}$ & pUCT127 & $\begin{array}{l}\text { Eco RI } \\
\text { Mbo I }\end{array}$ & $\begin{array}{l}3.8 \\
3.8\end{array}$ & $\begin{array}{l}3.8 \\
3.8\end{array}$ \\
\hline $130^{\mathrm{c}}$ & pUCT130 & $\begin{array}{l}\text { Bst EII } \\
\text { Eco RI } \\
M b o \text { I }\end{array}$ & $\begin{array}{l}2.9,1.0 \\
3.8 \\
3.8\end{array}$ & $\begin{array}{l}3.9 \\
3.8 \\
3.8\end{array}$ \\
\hline $132^{c}$ & pUCT132 & $\begin{array}{l}\text { Bst EII } \\
\text { Eco RI } \\
M b o \text { I }\end{array}$ & $\begin{array}{l}2.9,1.0 \\
3.8 \\
3.8\end{array}$ & $\begin{array}{l}3.9 \\
3.8 \\
3.8\end{array}$ \\
\hline $240^{c}$ & pUCT240 & $\begin{array}{l}\text { Bst EII } \\
\text { Eco RI }\end{array}$ & $\begin{array}{l}2.8 \\
3.0\end{array}$ & $\begin{array}{l}2.8 \\
3.0\end{array}$ \\
\hline${ }^{*} \mathrm{~T} 129$ a & pUCT129b & $B g l$ II & 5.0 & 5.0 \\
\hline
\end{tabular}

\section{B. Size of the plasmids}

Several plasmid types were found in size from $2.9 \pm 0.1$ to $7.6 \pm 0.2 \mathrm{~kb}$ (table 1). The unique plasmid of strains 43 and 44 is the same size : $7.6 \mathrm{~kb}$; they are respectively named pUCT43 and pUCT44. Strains 127, 130, and 132 each harboured a plasmid of identical size : $3.8 \mathrm{~kb}$, respectively named : pUCT127, pUCT130, and pUCT132. 


\section{Restriction analysis of plasmid DNA}

Each plasmid DNA was treated with a variety of restriction endonucleases. No activity was obtained with Ava I, Bam HI, Hae III, Hha I, Hind III, Kpn I, Pst I, Pvu II, Sal I, Xba I or Xho I.

Results of restriction analysis with $B g l$ II, Bst EII, Eco RI, Mbo I, and Taq I are reported in table 1 . Restriction pattern of pUCT43 and pUCT44 with $M b o$ I, BgI II and Taq I was very similar (table 1). The same can be said of plasmids pUCT4a, pUCT53a and pUCT240 hydrolysed with Bst EII and Eco RI. Plasmids pUCT127, pUCT130, and pUCT132 were similarly restricted with Mbo I and Eco RI (table 1); pUCT127 was not cleaved by Bst EII. The pUCT129b was only linearized by Bgl II and pUCT129a was cut with neither endonucleases used.

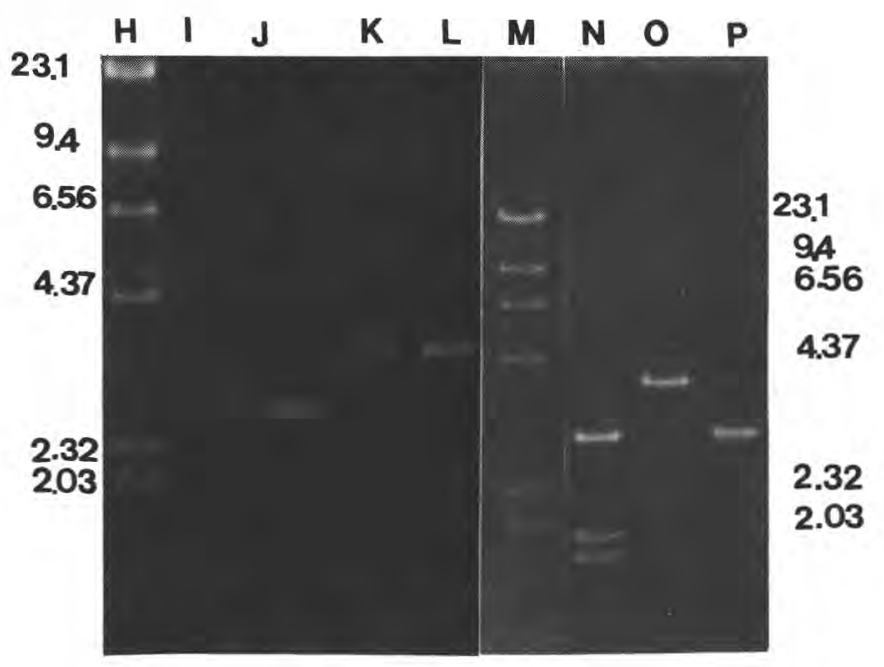

Fig. 1A

Agarose gel electrophoresis of plasmids from Streptococcus thermophilus hydrolysed by various restriction endonucleases. Tracks $H$ to $L$ : Agarose concentration : $0.8 \% ;(H)$ : lambda phage DNA Hind III fragments (control) ; (I) : pUCT 130 digested by Bst EII ; $(J)$ : pUCT132 digested with Bst EII ; $(K)$ : pUCT130 digested with Eco RI; $(L)$ : pUCT132 digested with Eco RI; Tracks $M$ to $P$ : Agarose concentration : $1 \%$; (M) : lambda phage DNA Hind III fragments (control); (N) : pUCT53a and $\dot{p} U C T 53 b$ digested with Eco RI; $(O)$ : pUCT127 digested with Eco RI; $(P)$ : pUCT240 digested with Eco RI.

Electrophorèse en gel d'agarose de plamides de Streptococcus thermophilus hydrolysés par diverses endonucléases de restriction.

Bandes $H$ à $L$ : concentration d'agarose de $0,8 \% ;(H)$ : fragments Hind III du phage lambda (contrôle); (I) : pUCT130 coupé par Bst EII; (J) : pUCT132 coupé par EcoRI ; $(L)$ : pUCT132 coupé par Eco RI. Bandes $M$ à P : concentration d'agarose de $1,0 \% ;(M)$ : fragments Hind III du phage lambda (contrôle); $(N)$ : pUCT53a et pUCT53b coupés par Eco RI ; $(O)$ : pUCT127 coupé par Eco RI ; $(P)$ : pUCT240 coupé par Eco RI. 


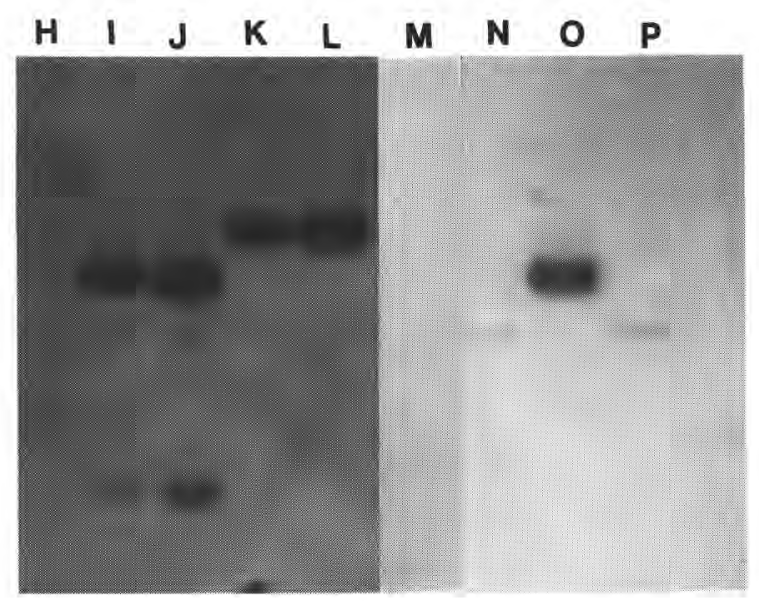

Fig. 1B

Autoradiogram of the Southern blot of both gels shown in figure $1 A$ with ${ }^{32} P$-labelled DNA pUCT130 used as a probe.

Autoradiogramme du buvardage selon Southern des deux gels représentés sur la figure $1 A$ après hybridation avec l'ADN du pUCT130 marqué au ${ }^{32} \mathrm{P}$ et utilisé comme sonde.

\section{DNA-DNA hybridization with ${ }^{32}$ P-labelled DNA probes from different plasmids}

Labelled pUCT43 probe hybridized with pUCT43 and pUCT44 plasmids and all their restriction fragments. No hybridization was observed with any other plasmids using this probe.

The pUCT130 probe only hybridized with pUCT130, pUCT127, and pUCT132 (fig. $1 \mathrm{~A}$ and 1B).

Whole labelled plasmid DNA from the strain 53 hybridized with pUCT240, pUCT4a, and both plasmids of the strain 53: pUCT53a and pUCT53b. No hybridization was observed with any other plasmids using this probe.

Neither plasmid from strain T129 nor pUCT4b ever hybridized with any probe assayed.

\section{Discussion-Conclusion}

By analysing 50 strains of different origins, we confirmed the paucity of plasmids in S. thermophilus (Herman and McKay, 1985 ; Somkuti and SteinBERG, 1986) : $9 / 50$ of the strains $(18 \%)$ harboured 1 or 2 plasmids and their small size : 2.9 to $7.6 \mathrm{~kb}$. Some of them were identical in size and in restriction analysis (table 1 ). 
Most of the plasmid types bore a single restriction site for one or two endonucleases and could be a potential source of plasmid vectors.

Among 23 strains isolated from commercial starters or obtained from collections, Herman and McKay (1985) found only 5 strains (from commercial sources) containing a single plasmid. Using DNA-DNA hybridization, they showed that all these plasmids belong to a single group of homology. In our study, we distinguished 8 plasmids by their size and their restriction fragments; we could easily classify them in 3 completely distinct groups of homology :

- pUCT43 and pUCT44;

- pUCT130, pUCT132 and pUCT127;

- pUCT240, pUCT4a, pUCT54b and/or pUCT53b.

These results indicated that the plasmids studied did not originate from a common ancestor as suggested by HERMAN and McKaY (1985).

Reçu le 3 novembre 1986.

Accepté pour publication le 25 février 1987.

\section{Acknowledgements}

We acknowledge M. BAILLEUL and the Laboratoire Interprofessionnel Laitier du Calvados to have provided us with raw milk and $D^{\prime} J$. STADHOUDERS for his strain sent to $D^{r} J$. REYROLLE. This work has been supported by grants from ANVAR, the Ministère de la Recherche et de l'Industrie, the Ministere de l'Education Nationale, the CNRS (Groupement Scientifique GS79 de Biologie de Caen) and the Conseil Régional de Basse Normandie.

\section{References}

Accolas J.P., Hemme D., Desmazeaud M.J., Vassal L., Boulllane C., Veaux M., 1980. Les levains thermophiles: Propriétés et comportement en technologie laitière. Lait, 60, 487-524.

Anderson D.G., McKay L.L., 1983. Simple and rapid method for isolating large plasmid DNA from lactic streptococci. Appl. Environ. Microbiol, 46, 549-552.

Davies F.L., Gasson M.J., 1983. Genetics of dairy cultures. Ir. J. Food. Sci. Technol., 7, 49-60.

Davies F.L., Underwood H.M., Gasson M.J., 1981. The value of plasmid profiles for strains identification in lactic streptococci and the relationship between Streptococcus lactis 712, ML3 and C2. J. Appl. Bacteriol., 51, 325-337.

Herman R.E., Mckay L.L., 1985. Isolation and partial characterization of plasmid DNA from Streptococcus thermophilus. Appl. Environ. Microbiol., 50, 1103-1106.

Hintermann G., Fisher H.M., Cramer R., Hutter R., 1981. Simple procedure for distinguishing $\mathrm{CCC}, \mathrm{OC}$ and $\mathrm{L}$ forms of plasmid DNA by agarose gel electrophoresis. Plasmid, 5, 371-373.

Maniatis T., Fritsch E.F., Sambrook J., 1982. Molecular cloning : a laboratory manual. Cold Spring Harbor Laboratory, ed. Cold Spring Harbor, New York, 387-389.

Ottagalli G., Galli A., Rondinini G., 1978. Ecologie des streptocoques thermophiles des produits laitiers. $\mathrm{XX}^{\mathrm{e}}$ Congr. Int. Lait, 525-526. 
Pechmann H., Geis A., Teuber M., 1982. Plasmide der michsäurestreptokokken. XXI Int. Dairy Congr., Vol. 1, Book 2, Moscow, USSR, MIR Publ., 352-353.

Sanger F., Coulson A.R., Hong G.F., Hill D.F., Petersen G.B., 1982. Nucleotide sequence of bacteriophage lambda DNA. J. Mol. Biol., 162, 729-773.

Somkuti G.A., Steinberg D.H., 1981. Plasmid deoxyribonucleic acid in Streptococcus thermophilus J. Dairy Sci., 64, Sup. 1, 66.

Somkuti G.A., Steinberg D.H., 1986. Distribution and analysis of plasmids in Streptococcus thermophilus. J. Ind. Microbiol., 1, 157-163.

Southern E.M., 1975. Detection of specific sequences among DNA fragments separated by gel electrophoresis. J. Mol. Biol., 98, 503-517.

Terzaghi B.E., Sandine S.E., 1975. Improved medium for lactic streptococci and their bacteriophages. Appl. Microbiol., 29, 807-813. 